\title{
Gender approaches in the study of the digital economy: a systematic literature review
}

Mónica Grau-Sarabia ${ }^{1,3 凶}$ \& Mayo Fuster-Morell ${ }^{2,3}$

The data and debates around the negative impact of online work for women's work-life balance during the digital acceleration generated by the COVID-19 crisis have lent greater relevance to the study of gender and the digital economy. This paper sheds light on this complex relationship by systematically studying the research on gender in the digital economy over the last 25 years. The methodology used is a systematic literature review (SLR) of scientific works and policy papers across different social sciences from 1995 to 2020 in the Google Scholars and Scopus databases. The SLR has resulted in the creation of three samples on which a quantitative and qualitative analysis was carried out to evaluate the volume of the research, trends across time, gender approaches and study topics. The general conclusions indicate that gender approaches to the digital economy stem from a wide range of academic disciplines, and also that there is a lack of theoretical consistency about gender analysis. First, the paper provides an overview of the volume of works and an analysis of some trends across time. Second, it identifies the three main gender approaches applied to the digital economy: (1) the 'feminist theory of technology and ICT' approach; (2) the 'feminist political economy' approach; (3) the 'mainstream economic analysis and women's participation and labour in the digital economy' approach. Moreover, it distinguishes eight main gender analysis issues within these three approaches. Finally, the paper concludes by identifying future developments for a feminist political economy framework for the digital economy.

\footnotetext{
${ }^{1}$ Dimmons Research Action Group. Internet Interdisciplinary Institute, Universitat Oberta de Catalunya, Barcelona, Spain. ${ }^{2}$ Berkman Center for Internet and

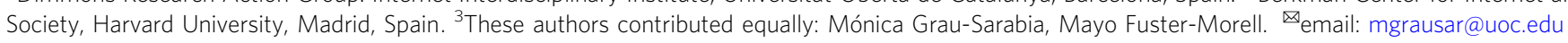




\section{Introduction}

round 25 years have passed since digital technologies began to develop and pervade almost every aspect of sociopolitical and economic life, giving rise to what is known as the 'Network Society' (Castells, 1996) and transforming most sectors of economic activity and the economy as a whole. It has also been 25 years since the Beijing Platform for Action (United Nations Women, 1995) set up the global agenda of social, political and economic gender equality. In March 2020, UN women published the report “Gender equality: Women's rights in review 25 years after Beijing” (United Nations Women, 2020a) and established 'harness technology for gender equality' as one of their four priorities. In fact, the benefits of the digital economy for gender equality were already on the international political agenda, as seen in reports such as "Going Digital: The Future of Work for Women" (OECD, 2017). However, over the course of only a few weeks in March, due to the situation created by COVID-19, the apparent agreement on the benefits of technology in women's lives turned into a political debate about gender inequalities related to teleworking and care responsibilities (United Nations Women, 2020b). In this regard, the COVID-19 crisis has evidenced the lack of clarity in the idea that the digital economy is a source or consequence of unequal gender relations and the need to investigate this complex interplay. The paper seeks to fill this gap by systematically studying the research conducted over the last 25 years to answer the research question: How has gender been studied in the digital economy?

The systematic literature review (SLR) methodology was designed to answer the following specific research questions: (i) How much research activity has been carried out into the interplay of gender and the digital economy and are there any trends? (ii) What gender approaches to the digital economy can be identified? And, what are the strengths and weaknesses of the different gender approaches? (iii) What are the specific gender issues being addressed? The findings of the paper will contribute to future research aimed at developing feminist politics on the digital economy and guide policymakers towards achieving gender equality within the digital economy.

The paper is structured around four sections. The first section provides a broad framework of the digital economy, followed by a gender analysis. The second section explains the extensive research methodology employed using an SLR, describing how the SLR was designed and then conducted. A mixed-method analysis of the results of the SLR is then performed whereby they are quantitatively and qualitatively analysed. The research on gender and the digital economy from a gender approach is then presented. The third section answers the paper's three research questions, starting with a quantitative analysis of the research activity and an initial identification of the research trends across time. Then, the three main gender and feminist approaches distinguished are presented. Furthermore, the eight specific gender issues identified in these three different approaches are outlined. Finally, the last section presents the conclusions and outlines some of the future challenges for feminism and global goals for gender equality in the digital economy.

\section{The digital economy and gender: departing framework}

A very specific, simple and straightforward definition of digital economy is "an economy based on digital technologies" (European Commission, 2013). A more developed one defines it as a compendium of the new economic developments and production and consumption transformations linked to digital technologies, information and communication technologies and new business models based on digital supports over the last 25 years (such as the platform economy and the data economy). It may be said that the digital economy has its origins in the Network Society and the intensive use of information and communication technologies (ICT) to create, distribute and manipulate information (Castells, 1996) that led to the digital revolution. This digital revolution is characterised by technological advances, the most important of which are the Internet, personal computers, smartphones, mobile internet, social media, cloud computing, the Internet of Things (IoT), artificial intelligence (AI), machine learning, big data, blockchain technologies, and robotics. Altogether with the range of different spheres of action and economic sectors, another characteristic of the digital economy is the variety of forms of economic relations and organisational models it may take, such as the emergence of what has been variously called the platform, digital, sharing, gig or collaborative economy as an emerging global phenomenon. Furthermore, digital platforms can draw from the economic frame of the social economy, as seen in platforms, open cooperatives (Scholz, 2016) and commonsoriented peer-to-peer platforms (Benkler, 2006; Fuster-Morell, 2010), which differ from digital platforms that arise out of an extremely ferocious capitalist corporate spirit (Srnicek, 2017). Thus, the digital economy is a floating signifier that involves many subfields and economic sectors.

The term 'gender' is popular in the language of social sciences, in part due to the feminist movement and the concurrent intellectual efforts to better understand the systematic and widespread subordination of women (Acker, 1992). Although the term is widely used, there is no common understanding of its meaning, even among feminist scholars (Butler, 1990). Gender interacts with, but is different to, the binary categories of biological sex. Gender is not only "a constitutive element of social relationships based on perceived differences between the sexes", but is also "a primary way of signifying relationships of power”, a field of norms and practices within which or through which power is articulated (Scott, 1986, p. 1067). Different academic disciplines have introduced gender analysis in their research agenda, developing rich interdisciplinary knowledge such as that of citizenship and gender (Lister and Campling, 2017) and urbanism and gender (Bondi and Rose, 2003) among many other examples. In all the cases, there is a certain agreement that the purpose of gender analysis is to identify gender inequalities and find solutions to them. However, the complexity comes from how gender is defined and how the analysis is approached. Thus, a gender approach from an understanding of gender as a binary social category offers only a surface-level analysis, describing empirical differences between men and women but without analysing or explaining the reasons for them. Conversely, a gender approach from a more complex understanding of gender as a power structure of inequalities involves a structural analysis of inequalities. The differences between gender analysis in feminist research and in other non-feminist research lie mainly in the fact that the former uses the feminist theoretical framework and the latter uses the term 'gender' to replace the term 'women'. These different understandings of gender can be considered as anchor points within a spectrum of gender approaches. Thus, the issue of the different gender approaches translates, on the one hand, into a critical analysis of structural power inequalities, for example, the study of the female exclusion mechanisms in the technology sector or the sexual labour division in immaterial labour; and, on the other hand, an analysis of the consequences of gender inequality relations, for example, the study of the low participation of females in the technology sector or women and men's different uses of social media. In light of past interdisciplinary gender studies, we expect to find different gender approaches in 


\section{Table 1 Methodology used in the paper to answer each of the specific questions.}

Research objectives

Keywords - for the conceptual framework and search
equations (Table 2)

Search engines

Inclusion criteria (listed in chronological order, see Table 3)

Exclusion criteria

First sample to answer RQ1

Second sample to answer RQ2 and RQ3
- To develop a broad conceptual framework of what the digital economy and gender analysis may involve

- To analyse quantitatively the total volume of research studying the interaction of gender and the digital economy and identify some trends

- To identify the gender approaches to the digital economy and analyse the strengths and weaknesses of each of them

- To distinguish the specific gender issues being addressed

- Keywords that refer to gender or feminist analysis: feminism, feminist theory, gender, and women

- Keywords that refer to the digital economy: technology, information communication technologies, digital economy, and sharing/platform/gig economy

- Google Scholar (GS) as the primary database because i) it indexes scholarly literature across a wide range of disciplines and publishing formats (articles, abstracts, books, conference proceedings, policy papers, theses, etc.) and ii) it enables searches to be made in an array of disciplines and sources in a single list

- Scopus as the secondary database to include academic works not indexed in the results of GS

1. All results from the 20 search equations in GS from 1995 to June 2020

2. The first 25 results sorted by relevance from 1995 to June 2020 for each of the 20 search equations in GS and in Scopus

3. Clustering the results by gender understandings and topics of analysis identified in the abstract and/or introduction, including relevant documents from the bibliography of selected papers in the clusters

Works whose titles, abstracts or introductions did not focus specifically on the digital economy and gender were rejected

First inclusion criteria: results from the 20 search equations in GS from 1995 to June 2020

Method: quantitative comparative data analysis (Table 4)

Second inclusion criteria and exclusion criteria: the first 25 results sorted by relevance from

1995 to June 2020 for each of the 20 search equations in GS and in Scopus

Exclusion criteria: not focusing on digital economy and gender

- Method: qualitative cluster analysis of the abstract or introduction

- Result: sample with 495 works

Third inclusion criteria: the most significant works for each gender approach and issue identified

- Method: qualitative analysis; in-depth content analysis

- Result: sample with 166 works the literature on digital economy and gender. Identifying and analysing these approaches may bring clarity to how the relationship between gender and the digital economy has been studied over time.

\section{Research methodology}

This paper aims to answer the question of how the relationship between gender and the digital economy has been studied over time by undertaking a systematic literature review (SLR). The SLR is "a systematic, explicit, comprehensive and reproducible method for identifying, evaluating, and synthesising the existing body of completed and recorded work produced by researchers, scholars, and practitioners" (Fink, 2019, p. 3). Currently, social sciences are adapting the initially developed SLR methodology from health sciences, and this paper represents an additional contribution to the few existing papers that have used this kind of research methodology.

To answer the three specific research questions, the method was adjusted following the indications described in some of the works produced within the fields of information systems and social sciences. Of particular relevance were the three main stages of the SLR proposed by Tranfield et al. (2003): planning the review, conducting the review and reporting results. This section will explain how the review was planned and conducted and the following section will report the results.

Designing of the SLR. The design or planning of the SLR for this research includes the steps described in Table 1 . It started with the development of a broad conceptual framework of what the digital economy and gender analysis may involve, together with the definition of the research objectives. It then went on to identify the keywords to be used for the search equations, followed by the selection of the search engines that are aligned with the rationale of including different scientific disciplines and works from both inside and outside academia. Additionally, the inclusion and exclusion criteria for the selection of works and the sampling process were defined. Moreover, finally, a description was provided of the expected samples and the analysis method for each of them.

Following the broad conceptual framework developed previously, the concept of digital economy is covered by words such as technology, ICT, sharing economy, platform economy, gig economy and digital economy. To refer to gender analysis, words are used such as: feminism, feminist theory, gender and women. All these words were used to create the twenty-five search equations (Table 2).

Conducting the SLR. The SLR was conducted around the three specific research questions:

(1) How much research activity has been carried out into the interplay of gender and the digital economy and are there any trends?

(2) Which gender approaches to the digital economy can be identified? And, what are the strengths and weaknesses of the different gender approaches?

(3) What are the specific gender issues being addressed?

The sampling process of the research was also structured to answer each of the research questions. The rationale of the sampling process was to transition from a very extensive sample 


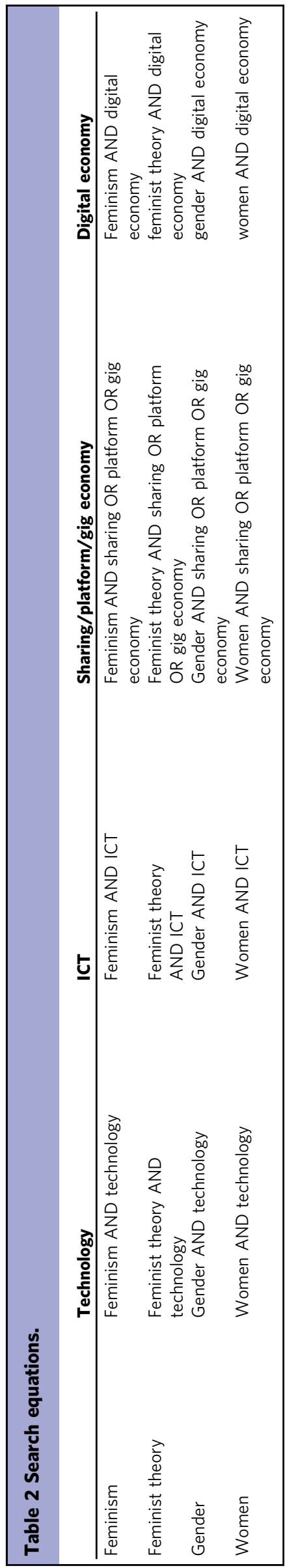

Table 3 Summary of the sampling process.

\begin{tabular}{|c|c|c|}
\hline Research questions & RQ1 & RQ2 \& RQ3 \\
\hline Searched by & All keywords & All keywords \\
\hline Searched in & Google Scholar & $\begin{array}{l}\text { Google Scholar } \\
\& \text { Scopus }\end{array}$ \\
\hline Date range & 1995 to June 2020 & 1995 to June 2020 \\
\hline 1st inclusion criteria & Yes & yes \\
\hline 2nd inclusion criteria & No & yes (495 results) \\
\hline Exclusion criteria & No & yes \\
\hline 3rd inclusion criteria & No & yes \\
\hline $\begin{array}{l}\text { Total number in } \\
\text { the sample }\end{array}$ & $1,026,66$ results & 166 results \\
\hline
\end{tabular}

to a more selective one. Thus, more inclusion criteria were required for the selection of works in all of the following samples. Table 3 describes the sampling process followed in this research.

The first sample was created based on the first inclusion criteria, that is, the results of the 25 search equations entered into GS, giving a total of 1,026,66 papers and research works. The aim of this first lax search was to get an overview of the entire body of research in the field conducted between 1995 and June 2020. The total number of results obtained in GS was considered as a proxy indicator of all the research, and the comparative analysis of results from each of the search equations was taken as an indicator of research trends.

The second sample was created in two steps. First, the second inclusion criteria were applied, that is, the first 25 results sorted by relevance from 1995 to June 2020 were taken for each of the 20 search equations in GS and in Scopus. GS has the benefit of indexing scholarly literature across a wide range of disciplines and publishing formats, unlike in academic databases, which was especially relevant for the purpose of this research. However, GS does not necessarily include all the results from peer-reviewed publications, whereas Scopus does. With the objective of balancing the strengths and weaknesses of GS, both search engines were used. After the deployment of a qualitative cluster analysis of the abstract and/or the introduction and the rejection of those works that did not focus on the digital economy and gender (exclusion criteria), 495 works were selected. The second step was then to deploy the third inclusion criteria; this was a qualitative analysis with an in-depth analysis of the content to create a second sample of 166 results. This second sample was analysed qualitatively to confirm the identified gender approaches to the digital economy and analyse the strengths and weaknesses of each of them, and to distinguish the specific gender issues being addressed. The total number of papers and research works included in this sample cannot aim to be the entire existing body of research but is a fairly accurate representation. The sample is available in an open database (gender approaches to the digital economy: selected database) to share with colleagues for future research in the field. The bibliographic reference manager Zotero was used to facilitate the management and analysis of both the second and third bibliography sample.

\section{Results of the gender research on the digital economy} RQ1. How much research activity has been carried out into the interplay of gender and the digital economy from 1995 to June 2020 and are there any trends? Table of the search-equation results from Google Scholar. The results of 25 search equations entered into Google Scholar were used as a proxy indicator of the entire body of research on this interplay, and the comparative analysis of results from each of the search equations as an 
Table 4 Results from the search on Google Scholar 1995-June 2020 for each search equation.

\begin{tabular}{llllll} 
& Technology & ICT & Digital economy & Sharing/platform/gig economy & Total \\
\hline Feminism & 206,000 & 204,000 & 4170 & 1426 & 415,596 \\
Feminist theory & 605,000 & 1940 & 2660 & 1466 & 611,066 \\
Gender & $1,960,000$ & 13,200 & 13,200 & 7760 & $1,994,160$ \\
Women & $1,710,000$ & 16,200 & 17,200 & 12,380 & $1,755,780$ \\
Total & $4,481,000$ & 235,340 & 37,230 & 23,032 & $1,026,66$ \\
\hline
\end{tabular}

indicator of trends (see Table 4). The quantitative comparison of results shows how several trends intersect. First, the use of the term 'gender' $(1,960,000)$ or 'women' $(1,755,780)$ was considerably more extensive than the use of 'feminist theory' $(611,066)$ and 'feminist' $(415,596)$. As explained by the conceptual framework, the term 'gender' has many different understandings. Gender analysis can stem from critical approaches that study power dynamics and the process of discrimination and structural inequalities on the grounds of gender, which are developed by feminism and feminist theory. However, gender analysis can also refer to a more uncritical or surface-level approach, for instance, the study of comparative differences among men and women in relation to a phenomenon, aimed at accounting for the reasons behind women's disadvantages. The major differences found in the use of 'gender' and 'women' and 'feminism' and 'feminist theory' seem to point to a greater trend to use the former approach. The second comparative difference is with the use of the term 'technology' $(4,481,000)$, which is relatively higher than the rest of the spheres of the digital economy analysed, followed by 'ICT' $(235,340)$, and the far less present 'digital economy' $(37,230)$, and finally 'sharing, platform or gig economy' (23,032). This suggests that gender analysis of the digital economy has focused more on the technological than the economic dimension. The third difference is 'feminist theory' has been used more to focus on 'technology' $(605,000)$ than in the rest the rest of the spheres of the digital economy analysed. Moreover, finally, the economic dimension (sharing, platform or gig economy and digital economy) has generally been analysed much less compared with technology and ICT. In addition, analysis of the economic dimension has focused on 'women' $(17,200-12,380)$ more than on 'feminism' (4.,170-1.,426) or 'feminist theory' $(2 ., 660-1 ., 466)$. This suggests that the economic dimension of the digital economy has been far less analysed from a gender perspective and any analysis has been uncritical, while critical gender analysis has focused mainly on technology.

The comparative analysis of the total results identifies some trends, such as a greater representation of gender analysis using an uncritical and surface-level approach; a greater representation of the gender analysis of the technological dimension of the digital economy than the economic dimension; and, finally, the more critical gender approach has focused on the technology dimension of the digital economy in contrast with the economic dimension, whose analysis seems to use a more superficial approach.

RQ2 What gender approaches to the digital economy can be identified? And, what are the strengths and weaknesses of the different gender approaches. The results of the in-depth analysis of the content methodology of the sample of 166 works allowed us to identify three central approaches across the work from 1995 to June 2020. These approaches are the 'feminist theory of technology and ICT'; the 'feminist political economy'; and 'women's participation and economic mainstream'. The full references of all these works can be found in the open database 'Gender approaches to the digital economy: selected database'.
The 'feminist theory of technology and ICT' approach: feminist framework on ICT and digital technology but no specifically economic dimension.

The first gender approach in the study of gender and the digital economy is characterised by a strong focus on feminist theory with a critical position about the structural inequalities of ICT and digital technology. There has been an extensive research tradition of feminist theories of technology, gender studies of technology and technofeminism since the beginning of the nineties to today, with the works of relevant academic authors such as Judy Wajcman, Cynthia Cockburn and Wendy Faulkner.

Many feminist technology studies have historically been motivated by a desire for political change (Wyatt, 2008). Early feminist responses to the digital revolution were largely optimistic about the potential of digital technologies, particularly ICT, to empower women and transform gender relations (Plant, 1997; VNS Matrix, 1995). Cyberspace seemed like a new gender-neutral space and a democratising and emancipatory platform for individuals, who had now become cyborgs (Haraway, 1990). The World Wide Web provided the first-ever public space accessible globally that connected women across the world (Youngs, 2015). However, soon, research on the feminist theory of technology proved that gender is embedded in technology itself and the digital revolution is taking place within the same patriarchal institutions, which contain structural gender inequalities. The fundamental contribution of this approach is the understanding of the social construction of technology, and that it is not gender neutral (Wajcman, 2010). Gender inequalities persist everywhere and digital technologies form part of the structure and performance of inequality (Wyatt, 2008). Technology may be gendered in various ways (Faulkner, 2001). Rather than conceiving of gender as fixed and existing independently of technology, the notion of performativity (Butler, 1990), or 'gender as doing', sees the construction of gender identities as shaped together with the technology in the making. Thus, both technology and gender are products of a moving relational process, emerging from collective and individual acts of interpretation (Wajcman, 2010). FTS scholars question the taken-for-granted association of men and machines as the result of the historical and cultural construction of gender. Similarly, the standard conceptions of innovation, production and work have been subject to scrutiny. Just as feminist economists have redefined the discipline of economics to take into account unpaid domestic and caring work (Folbre, 1994), FTS scholars have argued for the significance of everyday life technology.

In general, this approach is framed within the feminist discourse that draws upon poststructuralist, postmodernist and social constructivism. It focuses on the study of forms of gender exclusion and gender exploitation of digital technology based on identity and symbolic creations and recreations, and the creation of a social imaginary of dominant liberal narratives of empowerment (Fotopoulou, 2017). It advocates a change and transformation of digital technology for fair and equal purposes. However, it does not explore the significant material consequences on the living 
conditions of those suffering from gender-based discrimination, nor does it study how identity creations may be at the root of the unequal economic system, as the following approach will do.

The 'feminist political economy' approach: feminist framework on power and economics but no specifically ICT dimension.

Feminist theorists and feminist economics scholars have made a crucial contribution to developing the 'feminist political economy' approach in the study of the digital economy. Feminism in general and feminist economics in particular confront the new challenges that technology may pose for the way we relate to work and employment, to production, as well as the changes this will bring to our lives and to political participation (Agenjo-Calderón and Gálvez-Muñoz, 2019, p. 162).

The works of some relevant authors such as Kelly Jarret, Ursula Huws, and Tiziana Terranova have made use of the theoretical groundwork of feminist and autonomist Marxist and feminist economics, with notions such as immaterial labour, the social factory, unwaged domestic work and social reproduction and free labour. Some of the works from this approach are built on the work of relevant feminist scholars such as Silvia Federici and Carole Patman, who are cited by Van Doorn (2017); Betty Friedan, cited by Eichner (2016); and Angela Davis, Rosa Luxemburg, Dalla Costa and Nancy Fraser, cited by Fuchs (2018).

ICT may be seen as a new form of economy, but feminist studies have demonstrated that their structures substantially reflect the dominant neoliberal patterns of ownership and control that have characterised the industrialised economy (Youngs, 2010). Similarly to the feminist theory of technology, feminist economics scholars have evidenced the social construction of economics (Ferber and Nelson, 1993) and have helped to understand economics from a larger and more systemic perspective as a method of 'social provisioning', as the way in which humans collectively organise themselves in order to guarantee their survival (Power, 2004, p. 7). Feminist economics academics ${ }^{1}$ have criticised the dominant understanding of the economy as being determined by patriarchal epistemology and by a historically based social construction that is organised according to the main power relationships, with gender as a central category. In line with the feminist economics perspective, works from this approach have confirmed that the digital economy is not ahistorical nor a neutral process that has emerged from technology trends; rather, they emphasise that gig work is contingent on the social context that it draws upon and it (re) produces intersectional categories (Webster and Zhang, 2020).

The claim of the second wave of feminism, the personal is political (Millett, 1971), reconstructed the understanding of gender inequalities as structural problems such as work inequalities, violence or poverty. It meant an opening of 'private' matters to political and economic analysis and social discussion. For Marxist and socialist feminism, patriarchy was not just seen as a form of sexist oppression, but as the exploitation of houseworkers in capitalism. In the dual systems theory, both capitalism and patriarchy were responsible for women's oppression (Hartmann, 1979). In response to Marxists' singular focus on the 'public labour market', feminist scholars contributed an analysis of 'women's work'-reproductive and care work-as a key source of capital accumulation. The mutually constitutive relationship between production and reproduction of capitalism (Jarrett, 2015 ) is crucial to understanding new business models and forms of labour. It was from feminism that the 'intersectional' concept was developed as a legacy of black feminism to refer to the interrelated and overlapping of social categories such as gender, race and class, among others, which are mutually constitutive systems of oppression and discrimination (Crenshaw, 1990;
Valentine, 2007). Works from this approach analyse gender and intersectional inequalities or denounce the lack of intersectionality analysis in mainstream research. In addition, this approach mostly critiques the new neoliberal feminism of the digital economy, which endorses individualisation and market-based solutions to employment (Shade, 2018). It enlarges the study of feminised forms of economic productivity from feminist economics within the digital economy. In contrast to the previous approach, which focuses mainly on the study of gendered cultural processes in technology and ICT, this approach focuses, to a greater extent, on the gendered structure of the economy and the role that gendered economic dynamics play in the process of capital accumulation.

The 'mainstream economic analysis and women's participation and labour in the digital economy' approach: without a feminist framework on ICT but with a mainstream economic dimension.

The analysis of the interplay between women's labour and the digital economy started developing after 2010 with the boom of platform business models. Most of the reports and policy papers from major international institutions such as the United Nations, the European Commission or the European Parliament, and OECD and private organisations and associations such as the World Bank, the World Economic Forum and the GSMA are framed in this approach. It seems that in much of the literature on gender and digital economy has arisen in tandem with labour studies, sociology, ICT and media studies, the feminist theory has not arisen naturally. The study of gender in this approach employs mostly a surface-level analysis and is sometimes limited to women and men's differences in their participation in and uses of ICT and female labour and sectors.

The interactions of gender and the digital economy are analysed from a 'mainstream' perspective, which is mostly noncritical and androcentric. It shows clearly how "for many nonfeminist researchers, 'gender' is often seen as only relevant when women are at issue, and much of the emerging technology spaces are constructed as cisgendered male-only zones" (Shaw, 2014, p. 271). There is an excessive focus on 'women and men's' differences in access and participation, and, in some respects, this may contribute to the neglect in understanding how gender relations start with the conceptualisation of economic activity itself, the technological design, and so on. The gendered embodiment of the digital technology that supports these platforms, which is characteristic of the first approach, is not covered. The lack of background feminist theories is evident in the lack of feminist and gender authors and the widespread use of expressions such as 'gender impact of digital economy', while feminist theories of technologies have largely evidenced the dual relationship of gender and technologies to produce and reproduce inequalities (Wajcman, 2010), or how 'gender inclusion' denotes an intention to increase women's participation without questioning the status quo of a system that maintains exclusion mechanisms. In fact, authors from the feminist political economy approach, such as Ursula Huws, have pointed out that "...'the domestic labour debate' of the '70s has been somewhat underexplored in the current digital economic context with the increasing rise of on-demand services platforms" (Huws, 2019, p. 9). In fact, a recurrent issue is the analysis of the opportunities that the space and time flexibility of the platform economy gives to women as caregivers.

People who are responsible for caring for loved ones need the ability to fit their work schedules and their caregiving schedules together. That's where the new digital labour economy holds enormous promise. (Slaughter, 2015, p. 2). 


\section{Table 5 Gender issues addressed in the literature.}

\section{The 'feminist theory of technology and ICT' approach}

The gender embedment of digital technology (identity, symbolic, social imaginaries)

The feminist political agenda: advocacy, political activism and empowerment initiatives

Gender-based violence and sexual harassment in the digital economy

e.g., how gender is conceptualised as both a source and a consequence of gender relations (Wajcman, 2010); exploring ways in which technology may be gendered (Faulkner, 2001); analysing the gendering of domestic technology (home tech) such as the microwave (Cockburn and Ormrod, 1993) developing instruments and frameworks based on relevant feminist theories (i.e., Butler, 1990; Harding, 1986; Scott, 1986); identifying gender bias in artificial intelligence and automated decisionmaking systems; (Woods, 2018) and studying sexuality in code/space (Cockayne \& Richardson, 2017).

e.g., the denouncement of the lack of big data with gender analysis (D'lgnazio \& Klein, 2020; Perez, 2019); developing a feminist approach on technology (Layne et al., 2010), feminist design in computing (Bardzell \& Bardzell, 2016) or a feminist proposal for the Internet (Shaw, 2014; m Kee, 2017); studying feminist digital geographies (Elwood \& Leszczynski, 2018); and defending digital technology as women's liberation and cyberfeminism (Haraway, 1990; Plant, 1997; VNS Matrix 1995).

e.g., the explosion of uses of technology to combat domestic violence (Dimond et al., 2011); denouncing the violent sexism and misogyny that exist in online spaces (Shaw, 2014); violence in political activism (Baer, 2016); the global campaign against women (Take Back the Tech); and online sexual harassment (Megarry, 2014).

The 'feminist political economy' approach

New forms of value creation- commodification of care, domestic and leisure activities

e.g., the intersectional study of the marketization of gender norms in platform work (Flanagan, 2019; Van Doorn, 2017; Webster and Zhang, 2020); the analysis of neoliberal socio-economic logics and post-racial and gender-neutral fantasy of the ondemand economy (Atanasoski \& Vora, 2015; Fuchs, 2018; Shade, 2018); exploring the notions of success in the media and female postmillennial digital economy (fashion bloggers) (Pham, 2013) and social media production in general (e.g., fashion, beauty, retail) (Duffy, 2015); understanding gendered dimensions of digital work (Arcy, 2016); developing a typology of the digitalisation and the commodification of domestic labour (Huws, 2019); and studying the nature of consumer online activities with the concept 'digital housewife' (Jarrett, 2015, p. 17).

Economic epistemology and dichotomy of work; the sexual division of labour: public vs private, productive vs reproductive

e.g., the regulation of the market to serve women's interests; 'market-cautious feminism' (Eichner, 2016); discussing whether the digital economy promotes women's rights (Shejni, 2019); discussing platform promises of gender inclusion and making women's gig work-home space visible (James \& Temple, 2019); demanding a feminist framework for new 'feminist digital economics' (Faith, 2018); and framing the economic geography in the new economy with a feminist perspective on social reproduction (Perrons, 2004).

The intersectionality analysis and perspectives from the Global South e.g., the study of the diversity of issues and different experiences of globalisation and ICT in developing countries (Geertsema, 2006; Mitter, 2004; Ng \& Mitter, 2005); criticising UNDP's human development approach on ICT as gender neutral and ignoring global power relations in the economy (Kwami et al., 2011; Lee, 2011); studying technocapitalism in India (Gupta, 2019); and promoting a global feminist political economic study of women's relations to the new information and communication technologies (Lee, 2006).

The 'mainstream economic analysis and women's participation and labour in the digital economy' approach

Women's access to and use of the digital economy

e.g., the study of the nature and areas of gender divides (Herbert, 2017) and located in specific regions such as Europe (Davaki, 2018); identifying women's disparities in access, capacity to use and ways of engaging with ICT (UNCTAD, 2019); and actions to reduce the gender digital divide through policy interventions (Ambujam \& Venkatalakshmi, 2009) at the European level (Davaki, 2018); ways to promote female talent in STEM professions (Propel London, 2019; Rowntree, 2020; WISE, 2017), also with a focus on developing countries (Sharmin, 2019) and to encourage girls to study and choose STEM careers (Ansip, 2016); the sex difference in the occupational structure of the digital economy (Piasna \& Drahokoupil, 2017); female workers' experiences in the gig economy (Hunt \& Samman, 2019); and the gender pay gap in the gig work platform economy (Foong et al., 2018).

Time and space flexibility in work e.g., how the space and time flexibility of the 'platform work' economy is claimed to be a positive alternative to traditional employment for those with family responsibilities, especially women (Schoenbaum, 2016) and as a chance for a more inclusive labour market (Carchio, 2019); considering flexibility as the main advantage that digital labour platforms can offer to female workers as caregivers (Ravanera, 2019); the study of how greater work flexibility can increase women's employment in conjunction with concerns about job quality (OECD, 2017); and the reduction of gender gaps in participation in the labour force by making working arrangements more flexible (World Bank Group, 2016).

As was mentioned for the previous approaches, this approach does not suppose a homogenous corpus of works and authors' point of view. It does include some important critical authors on the platform economy such as Judy Schor, because although she works on discrimination and inequalities, including gender inequalities, she does not include any explicit feminist framework; or books such as Gender and Innovation in the New Economy (Poutanen and Kovalainen, 2017), because it represents, to a greater extent, a mainstream economic approach with its mostly business-focused literature.
This approach encompasses important works of international institutions and appears to pique the interest of ICT scholars. The analysis of the research activity and trends in gender analysis in the study of the digital economy showed that this approach has abounded most in recent years. The lack of a gender analysis beyond the empirical difference between women and men may be due to the lack of or difficulty in applying gender analysis tools in the field and the lack of study of feminist theories and gender studies in interdisciplinary works. 
RQ3 What are the specific gender issues being addressed?. The in-depth content analysis of the sample of 166 works also enabled us to identify eight specific gender issues found across the three different gender approaches. Table 5 lists the gender topics addressed and some examples of works for each of them. The full references of all these works can be found in the open database 'Gender approaches to the digital economy: selected database'.

\section{Conclusion}

Based on an SLR, the analysis shows that gender analysis on the digital economy has been limited and unsystematized, and needs to be expanded and explored in greater depth, while a dialogue about it needs to be started to create coherence. Although the research was limited, three main approaches are have been identified in the study of the interplay of gender and the digital economy: the 'feminist theory of technology and ICT' approach; the 'feminist political economy' approach; and the 'mainstream economic analysis and women's participation and labour in the digital economy' approach. Each has its strengths and limitations and addresses elements related to gender and the digital economy, but overall the study highlights the lack of a direct feminist gender critique of the digital economy.

The term gender approach is not a homogeneous one but it reflects a broad compendium of gender inequality analysis ranging from more structural to more surface level. The wide range of issues and how they are approached is proven by the diversity of issues addressed: the gender embedment of digital technology (identity, symbolic, social imaginaries); the women's rights agenda: advocacy, political activism and empowerment initiatives; gender-based violence and sexual harassment in the digital economy; new forms of value creation-commodification of care, domestic and leisure activities; economic epistemology and dichotomy of work; the sexual division of labour: public vs. private, productive vs. reproductive; women's access to and use of the digital economy; and time and space flexibility in work. Other gender issues were found among the works, such as intimacy and sexuality in the digital economy; privacy, data and surveillance; and free and open source software movements and gender, but these were not mentioned as they are less present.

Gender approaches have been also characterised on the basis of their feminist and critical foundations. However, even if gender analysis has been developed through feminist and critical issues, this does not necessarily mean that the analysis was critical and based on feminist theory. For the future development of this field -and we hope that this paper helps to move in this direction-it would be beneficial to start a dialogue about the diverse gender conceptions. In this respect, it would be useful for future research to develop a framework of the diverse gender dimensions and feminist qualities in the digital economy.

Finally, despite the plurality of elements analysed, there are still many areas of the digital economy, some of which are key elements that have not been explicitly analysed, such as digital business models and the platform economy, or gender plans specific to the digital sphere.

\section{Data availability}

The datasets generated during and/or analysed during the current study are available in the Gender approaches to the digital economy: selected database repository, https://docs.google.com/ document/d/1xxvRQS545GEeJaHpT_NxuA6Vne8hUWrSdtX8d SFlmR4/edit?pli=1\#heading $=$ h.15wy8shuwllc

Received: 26 March 2021; Accepted: 13 July 2021; Published online: 23 August 2021

\section{Note}

1 Some relevant scholars in the field are Lourdes Benería, Diana Strassmann, Nancy Folbre, Marilyn Power, Marianne A. Ferber, Julie A. Nelson, Michele Pujol, Marilyn Waring, Sabina Alkire, Naila Kabeer, Amartya Sen, Cristina Carrasco, Amaia PérezOrozco, Corina Rodriguez, Antonella Picchio, Angela O’Hagan, Maria Rosa Dalla Costa and Silvia Federici.

\section{References}

Acker J (1992) From sex roles to gendered institutions. Contemp Sociol 21 (5):565-569. https://doi.org/10.2307/2075528

Agenjo-Calderón A, Gálvez-Muñoz L (2019) Feminist economics: theoretical and political dimensions. Am J Econ Sociol 78(1):137-166. https://doi.org/ 10.1111/ajes.12264

Ferber MA, Nelson JA (Eds) (1993) Beyond economic man: feminist theory and economics. University of Chicago Press, Chicago, IL

Ambujam NK, Venkatalakshmi K (2009) The function of information and technology in empowerment of women. 385-387. Scopus. https://doi.org/10.1109/ ICCSIT.2009.5234705

Ansip A (2016) Working to get more European women into digital and ICT careers -Parlementaire monitor. https://www.parlementairemonitor.nl/9353000/1/ j9vvij5epmj1ey0/vk3mm44lcozn?ctx $=$ vhyzn0vt5cvu\&tab $=1 \&$ start_tab0 $=40$

Arcy J (2016) Emotion work: Considering gender in digital labor. Feminist Media Studies 16(2):365-368

Atanasoski N, Vora K (2015) Surrogate humanity: Posthuman networks and the (racialized) obsolescence of labor. Catalyst:Feminism, Theory, Technoscience, $1(1)$

Baer H (2016) Redoing feminism: Digital activism, body politics, and neoliberalism. Feminist media studies 16(1):17-34

Bardzell S, Bardzell J (2016) Feminist Design in Computing. The Wiley Blackwell Encyclopedia of Gender and Sexuality Studies, 1-7

Bauwens M (2005) The political economy of peer production. Post-autistic economics review, issue no. 37, 28 April 2006, article 3, pp. 33-44, Retrieved May 15, 2020 from: http://www.paecon.net/PAEReview/issue37/Bauwens37.htm

Benkler Y (2006) The wealth of networks: how social production transforms markets and freedom. New Haven and London: Yale University Press

Bondi L, Rose D (2003) Constructing gender, constructing the urban: a review of Anglo-American feminist urban geography. Gend Place Cult: J Fem Geogr 10 (3):229-245. https://doi.org/10.1080/0966369032000114000

Butler J (1990) Gender trouble: feminism and the subversion of identity. Routledge, Nueva York, NY

Carchio C (2019) Platform work as a chance for a more inclusive labour market. En V. Filli \& F. Constantini (Eds), Legal Issues in the Digital Economy: The Impact of Disruptive Technologies in the Labour Market (p. 73). Cambridge Scholars Publishing

Castells M (1996) The information age, Vol. 1: the rise of the network society. Blackwell, Cambridge, MA and Oxford

Cockayne DG, Richardson L (2017) Queering code/space: The co-production of socio-sexual codes and digital technologies. Gender, Place \& Culture 24 (11):1642-1658. https://doi.org/10.1080/0966369X.2017.1339672

Cockburn C, Ormrod S (1993) Gender and technology in the making. SAGE Publications Ltd

Crenshaw K (1990) Mapping the margins: intersectionality, identity politics, and violence against women of color. Stan L Rev 43:1241

D'Ignazio C, Klein LF (2020) Data feminism. MIT Press

Davaki K (2018) The underlying causes of the digital gender gap and possible solutions for enhanced digital inclusion of women and girls. FEMM: Women's Rights and Gender Equality

Dimond JP, Fiesler C, Bruckman AS (2011) Domestic violence and information communication technologies. Interacting with Computers 23(5):413-421

Van Doorn N (2017) Platform labor: on the gendered and racialized exploitation of low-income service work in the 'on-demand'economy. Inform Commun Soc 20(6):898-914. https://doi.org/10.1080/1369118X.2017.1294194

Duffy BE (2015) Gendering the labor of social media production. Feminist Media Studies 15(4):710-714

Eichner M (2016) Market-cautious feminism. STUD. L., POL. \& SOC'Y 69:141-160

Elwood S, Leszczynski A (2018) Feminist digital geographies. Gender, Place \& Culture 25(5):629-644. https://doi.org/10.1080/0966369X.2018.1465396

European Commission (2013) Expert group on taxation of the digital economy. Retrieved July 10, 2020 from: https:/ec.europa.eu/taxation_customs/sites/ taxation/files/resources/documents/taxation/gen_info/good_governance_matters/ digital/report_digital_economy.pdf

Faith B (2018) Why we need a 'feminist digital economics'. GenderIT.Org. https:// www.genderit.org/feminist-talk/why-we-need-\%E2\%80\%98feminist-digitaleconomics $\% \mathrm{E} 2 \% 80 \% 99$ 
Faulkner W (2001) The technology question in feminism: a view from feminist technology studies. In Women's studies international forum. 24(1), 79-95. https://doi.org/10.1016/S0277-5395(00)00166-7

Fink A (2019) Conducting research literature reviews: from the internet to paper. SAGE Publications. London

Flanagan F (2019) Theorising the gig economy and home-based service work. Journal of Industrial Relations 61(1):57-78

Folbre N (1994) Who pays for the kids?: gender and the structures of constraint. New York: Routledge

Foong E, Vincent N, Hecht B, Gerber EM (2018) Women (still) ask for less: Gender differences in hourly rate in an online labor marketplace. Proceedings of the ACM on Human-Computer Interaction, 2(CSCW). Scopus. https://doi.org/ $10.1145 / 3274322$

Fotopoulou A (2017) Feminist activism and digital networks: between empowerment and vulnerability. Basingstoke: Palgrave Macmillan

Fuchs C (2018) Capitalism, patriarchy, slavery, and racism in the age of digital capitalism and digital labour. Crit Sociol 44(4-5):677-702. https://doi.org/ $10.1177 / 0896920517691108$

Fuster Morell M (2010) Governance on Line Creation Communities: Provision of Infraestructure for the Building of Digital Commons, San Domenico di Fiesole, European University Institute. Ph.D. Dissertation, September, mimeo

Geertsema M (2006) Gender and the Digital Economy: Perspectives from the Developing World

Gupta H (2019) Testing the Future: Gender and Technocapitalism in Start-Up India. Feminist Review 123(1):74-88. https://doi.org/10.1177/0141778919879740s

Haraway D (1990) A manifesto for cyborgs: science, technology, and socialist feminism in the 1980s. in Linda J.Nicholson (ed.) Feminism/Postmodernism, New York: Routledge: 190-233

Harding S (1986) The science question in feminism (Ithaca). Cornell University Press

Hartmann HI (1979) The unhappy marriage of Marxism and feminism: towards a more progressive union. Capital Class 3(2):1-33. https://doi.org/10.1177/ 030981687900800102

Herbert S (2017) Digital development and the digital gender gap

Hunt A, Samman E (2019) Gender and the gig economy

Huws U (2019) The hassle of housework: digitalisation and the commodification of domestic labour. Fem Rev 123(1):8-23. https://doi.org/10.1177/ 0141778919879725

James A, Temple J (2019) Feminising the Platform Economy? WorkforceNewBridge Project Zine

Jarrett K (2015) Feminism, labour and digital media: the digital housewife. New York: Routledge

Kwami JD, Wolf-Monteiro B, Steeves HL (2011) Toward a 'macro-micro'analysis of gender, power and ICTs: A response to Micky Lee's feminist political economic critique of the human development approach to new ICTs. International Communication Gazette 73(6):539-549

Layne LL, Vostral SL, Boyer,K (2010) Feminist technology (Vol. 4). University of Illinois Press

Lee M (2006) What's missing in feminist research in new information and communication technologies? Feminist Media Studies 6(2):191-210

Lee M (2011) A feminist political economy of communication. Feminist Media Studies 11(01):83-87

Lister R, Campling J (2017) Citizenship: feminist perspectives. Basingstoke: Macmillan -now Palgrave Macmillan

Megarry J (2014) Online incivility or sexual harassment? Conceptualising women's experiences in the digital age. Women's Studies International Forum $47: 46-55$

Millett K (1971) Sexual politics. London: Rupert Hart-Davis

Mitter S (2004) Globalization, ICTs, and economic empowerment: a feminist critique. Gender, Technology and Development 8(1):5-29. https://doi.org/ $10.1080 / 09718524.2004 .11910104$

Ng C, Mitter, S (2005) Gender and the digital economy: Perspectives from the developing world. Sage

OECD (2017) Going digital: the future of work for women, policy brief on the future of work. Organisation for Economic Cooperation and Development Paris. Retrieved September 23, 2020 from: https://www.oecd.org/ employment/Going-Digital-the-Future-of-Work-for-Women.pdf

Perez CC (2019) Invisible women: Exposing data bias in a world designed for men. Random House

Perrons D (2004) Understanding social and spatial divisions in the new economy: New media clusters and the digital divide. Economic geography 80(1):45-61

Pham MHT (2013) "Susie Bubble is a Sign of The Times" The embodiment of success in the Web 2.0 economy. Feminist Media Studies 13(2):245-267

Piasna A, Drahokoupil J (2017) Gender inequalities in the new world of work. Transfer: European Review of Labour and Research 23(3):313-332

Plant S (1997) Zeros and ones: digital women and the new Technoculture Londres, Fourth Estate
Poutanen S, Kovalainen A (2017) New economy, platform economy and gender In: Poutanen S, Kovalainen A (eds.) Gender and innovation in the new economy: women, identity, and creative work. Palgrave Macmillan, US, pp. $47-96$

Power M (2004) Social provisioning as a starting point for feminist economics. Fem Econ 10(3):3-19. https://doi.org/10.1080/1354570042000267608

Propel London (2019) Digital Nation: Funding The Digital Economy. https://www. empowerwomen.org/en/resources/documents/2019/05/digital-nationfunding-the-digital-economy?lang=en

Ravanera C (2019) Towards a more equitable gig economy. https://www. gendereconomy.org/equitable-gig-economy/

Rowntree O (2020) The Mobile Gender Gap Report 2020. https:/www.gsma.com/ mobilefordevelopment/resources/mobile-gender-gapreport-2019/

Schoenbaum N (2016) Gender and the sharing economy. Fordham Urb. LJ 43:1023

Scholz T (2016) Platform cooperativism. Challenging the corporate sharing economy. Rosa Luxemburg Foundation, New York, NY

Scott JW (1986) Gender: a useful category of historical analysis. Am Hist Rev 91 (5):1053-1075. https://doi.org/10.2307/1864376

Shade LR (2018) Hop to it in the gig economy: the sharing economy and neoliberal feminism. Int J Media Cult Polit 14(1):35-54. https://doi.org/10.1386/ macp.14.1.35

Sharmin S (2019) Bridging female entrepreneurs using ICT. Proceedings of Asian CHI Symposium 2019: Emerging HCI Research Collection, 90-97

Shaw A (2014) The internet is full of jerks, because the world is full of jerks: What feminist theory teaches us about the internet. Commun Crit/Cult Stud 11 (3):273-277. https://doi.org/10.1080/14791420.2014.926245

Shejni L (2019) Technology Is Not the Great Equalizer: A Feminist Perspective on the Digital Economy. Development 62(1-4):128-135

Slaughter A-M (2015) Unfinished business: women men work family. London, Oneworld Publications

sm Kee J (2017) Imagine a Feminist Internet. Development 60(1-2):83-89

Srnicek N (2017) Platform capitalism. Cambridge: Polity

Tranfield D, Denyer D, Smart P (2003) Towards a methodology for developing evidence-informed management knowledge by means of systematic review. $\mathrm{Br}$ J Manag 14(3):207-222. https://doi.org/10.1111/14678551.00375

UNCTAD (2019) Digital economy report 2019: Value creation and capture : implications for developing countries. United Nations Conference on Trade and Development

United Nations Women (1995) Fourth World Conference on Women. Retrieved June 20, 2020 from: https://www.un.org/womenwatch/daw/beijing/platform/

United Nations Women (2020a) UN Secretary-General's policy brief: the impact of COVID-19 on women Retrieved June 20, 2020 from: https://www.unwomen org/en/digital-library/publications/2020/04/policy-brief-the-impact-of-covid19-on-women

United Nations Women (2020b) Gender equality: women's rights in review 25 years after Beijing |. Retrieved June 20, 2020 from: https://www.unwomen. org/en/digital-library/publications/2020/03/womens-rights-in-review

Valentine G (2007) Theorizing and researching intersectionality: a challenge for feminist geography. Prof Geogr 59(1):10-21. https://doi.org/10.1111/j.14679272.2007.00587.x

VNS Matrix (1995) Welcome to the world of ALL NEW GEN/VNS Matrix. VNS Matrix. Retrieved July 10, 2020 from: https://vnsmatrix.net/publications/ welcome-to-the-world-of-all-new-gen

Wajcman J (2010) Feminist theories of technology. Camb J Econ 34(1):143-152. https://doi.org/10.1093/cje/ben057

Webster NA, Zhang Q (2020) Careers delivered from the kitchen? Immigrant women small-scale entrepreneurs working in the growing nordic platform economy. Nord J Fem Gend Res, 1-13. https://doi.org/10.1080/ 08038740.2020 .1714725

WISE (2017) Women in STEM workforce 2017. Welcome to the WISE Campaign. https://www.wisecampaign.org.uk/statistics/women-instem-workforce-2017/

Woods HS (2018) Asking more of Siri and Alexa: Feminine persona in service of surveillance capitalism. Critical Studies in Media Communication 35 (4):334-349. https://doi.org/10.1080/15295036.2018.1488082

World Bank Group (2016) World Development Report 2016: Digital Dividends. Retrieved September 12, 2020 from: https://www.worldbank.org/en/ publication/wdr2016

Wyatt S (2008) Feminism, technology and the information society. Learning from the past, imagining the future. Inform Community Soc 11(1):111-130. https://doi.org/10.1080/13691180701859065

Youngs G (2010) "Globalization, Feminism and Information Society." In Gender and Global Restructuring, 2nd ed., edited by M. Marchand and A. Sisson Runyan. London: Routledge, 223-238

Youngs G (2015) Digital transformations of transnational feminism in theory and practice. The Oxford Handbook of Transnational Feminist Movements, Oxford University Press 


\section{Competing interests}

The authors declare no competing interests.

\section{Additional information}

Supplementary information The online version contains supplementary material available at https://doi.org/10.1057/s41599-021-00875-x.

Correspondence and requests for materials should be addressed to M.G-S.

Reprints and permission information is available at http://www.nature.com/reprints

Publisher's note Springer Nature remains neutral with regard to jurisdictional claims in published maps and institutional affiliations. (c) (i) Open Access This article is licensed under a Creative Commons Attribution 4.0 International License, which permits use, sharing, adaptation, distribution and reproduction in any medium or format, as long as you give appropriate credit to the original author(s) and the source, provide a link to the Creative Commons license, and indicate if changes were made. The images or other third party material in this article are included in the article's Creative Commons license, unless indicated otherwise in a credit line to the material. If material is not included in the article's Creative Commons license and your intended use is not permitted by statutory regulation or exceeds the permitted use, you will need to obtain permission directly from the copyright holder. To view a copy of this license, visit http://creativecommons.org/ licenses/by/4.0/.

(C) The Author(s) 2021 